\title{
Multidisciplinary Nature of the Psycholinguistic Discourse Neuroeconomics
}

\section{Мультидисциплинарный характер психолингвистического дискурса нейроэкономики}

\author{
Tamara Tkach ${ }^{1}$ \\ Dr. in Psychology, \\ Professor
}

\author{
Тамара Ткач ${ }^{1}$ \\ доктор психологических наук, \\ профессор
}

E-mail: tkachtam@gmail.com https://orcid.org/0000-0001-5290-5395

ResearcherID: AAD-9363-2020

\section{Anatoliy Tkach ${ }^{2}$}

Dr. in Economics,

Professor
Анатолий Ткач ${ }^{2}$

доктор экономических наук, профессор

E-mail: tkachprof@gmail.com https://orcid.org/0000-0002-7207-117X

ResearcherID: AAD-9394-2020

\section{Ivan Rekun ${ }^{3}$}

Dr. in Economics,

Professor

\section{Иван Рекун ${ }^{3}$}

доктор экономических наук, профессор

E-mail: docrekun@gmail.com

https://orcid.org/0000-0002-3536-7369

ResearcherID: H-7728-2018

${ }^{1}$ Pereiaslav-Khmelnytskyi

Hryhorii Skovoroda State

Pedagogical University

$\triangle$ 30, Sukhomlynskyi Str.,

Pereiaslav, Kyiv Reg., 08401
${ }^{1}$ ГВУЗ «Переяслав-

Хмельниикий государственный педагогический университет имени Григория Сковороды» $\triangle$ ул. Сухомлинского, 30, Переяслав, Киевская обл.,

Украина, 08401 
Multidisciplinary Nature of the Psycholinguistic Discourse...

${ }^{2}$ University of Technology, Rzeszow

12, Aleja Powstańców Warszawy, Rzeszów, 35-959

\author{
${ }^{3}$ Dnipro National University \\ of Railway Transport named \\ after Academician V. Lazaryan \\ $\triangle$ 2, Lazaryana Str., Dnipro, \\ Dnipropetrovsk reg., Ukraine, \\ 49010
}

${ }^{2}$ Жешувский политехнический университет

Аллея Варшавского восстания, 12, Жешув, Польша, 35-959

\author{
${ }^{3}$ Днепровский национальный \\ университет железнодорожного \\ транспорта имени \\ академика В. Лазаряна \\ $\bowtie$ ул. Лазаряна, 2, Днепр, \\ Днепропетровская обл., \\ Украина, 49010
}

Original manuscript received November 10, 2019

Revised manuscript accepted March 10, 2020

\begin{abstract}
Introduction. The article is devoted to the issues of multidisciplinary interaction in new scientific fields, which involve a wide variety of convergences, no matter how strange at first glance they may seem. One of these phenomena is the interaction of psycholinguistics and neuroeconomics.

The goal. The article examines the transition of modern science to multidisciplinary discourse, which makes it necessary to conceptualize and possibly operationalize methods of psycholinguistics. The conceptualization of new areas of neuroeconomics, in a psycholinguistic context, presupposes a certain mental experience that includes, in addition to the processes of creating new concepts and contextual economic knowledge, also defining the role of interests, intentions, emotions in human economic activity.
\end{abstract}

Methods. Multivariate analysis, comparative analysis, extrapolation.

Results. It is proved that in recent decades the development of new areas of economic science, namely those related to the development of neuroeconomics, has significantly expanded the field of psycholinguistics. The production of new paradigms of economic theory, the formation of the corresponding definitions, objects requires the design and definition of them both in form and in content. It considers the need for a theoretical and orderly definition of the functional meaning of the psycholinguistic context of new definitions, the result of which can be a conceptual system for communication between specialists in various fields of science at the level of their professional understanding. It seems that the central issues in the psycholinguistic discourse of neuroeconomics have become the relationship between economics, psychology, linguistics and psycholinguistics. Such connection is undoubtedly of a multidisciplinary nature, which contributes to the deepening of the relationship between scientific thought, culture and language and became the impetus for understanding the nature of human cognition at a higher, multidisciplinary level of development of science. 
This is a necessary component for understanding the meanings and structure of concepts, terms and definitions, as well as communications at a higher scientific level. Conclusions. It is concluded that new areas of neuroeconomics such as behavioral economics, behavioral finance, emotional economics, psychological economics, have become areas of economic theory that, explicitly or implicitly, take into account the psychological characteristics of human perception and behavior in the process of economic activity. These definitions catalyze the theoretical integration of various scientific fields, and, above all, psycholinguistic science.

Key words: multidisciplinary nature of research, psycholinguistic discourse, neuroeconomics, behavioral economics, behavioral finance, psychological economics, emotional economics.

\section{Вступление}

Развитие новых областей экономической теории в последние десятилетия, а именно тех, которые связаны с нейроэкономикой, значительно расширили поле психолингвистики как эффективного механизма языковой обработки новых современных дефиниций. Психолингвистика, которая непосредственно имеет дело с психическими процессами, участвующими в продуцировании и понимании речи, определяет отношения между языком человека и его разумом, а именно, каким образом слово, предложение и значение дискурса представляются и усваиваются в процессе умственной деятельности. Это составляет суть научной дискуссии о проблеме мышления и языка, и о том, как мы воспринимаем психолингвистическую реальность. Подразделяется ли физический мир на естественные категории, которые люди легко распознают (реалистический взгляд)? Или они видят мир с точки зрения категорий, которым научил нас наш язык (конструктивистский взгляд)?

В экономической науке сложилась такая удивительная ситуация, что еще лет 20-25 назад многих дефиниций, терминов и даже новых ее сфер просто не существовало. На начальном этапе этого периода в научной среде испытывали состояние некоторого потрясения, когда возникла необходимость в дефиницировании многих новых понятий, которые имеют отношение к новым направлениям экономической теории. Это произошло по мере 
углубления и расширения знаний о нейронных, психологических, лингвистических и биологических особенностях восприятия и обработки информации. Ученые в разных научных сферах все больший интерес стали проявлять к механизмам мотиваций и действий на основе принятия решений, теории выбора и моделирования поведения субъектов экономической деятельности. Из многих нововведений наибольшее развитие получили двойственные понятия экономики, нейропсихологии, психологии других научных сфер. В процессе мультидисциплинарных коммуникаций на концептуальном уровне возникают проблемы, связанные с использованием учеными непривычных методов обоснования теоретического знания, а именно, с разным пониманием равнозначных понятий и терминов. Но в создании соответствующих лингвистических коммуникативных кодов и средств только одной лингвистики не достаточно. Важным является и то, каким образом формируется структура научного языка, и, в равной мере, то, как он обрабатывается людьми. Таким образом, речь идет о психолингвистике. В XXI веке психолингвистика становится неотъемлемой частью когнитивных наук.

Цель статьи заключается в теоретическом обосновании и расширении психолингвистического анализа мультидисциплинарного формата новых сфер экономической теории, который основан на новых достижениях в нейроэкономике и ее модификациях.

Несмотря на распространенность и актуальность терминов, используемых для обозначения новых разделов экономической теории, психолингвистические и содержательные характеристики этой важной части лексико-семантической области никогда не были специально исследованы. В статье сделана попытка объяснить чрезвычайную неуловимость новых психолингвистических идей в создании нормированной структуры дефиниций, связанных с новыми разделами современной экономической теории.

Ведущими становятся вопросы, каким образом следует понимать связи между экономикой, психологией, лингвистикой и психолингвистикой. Было признано, что такая связь, несомненно, имеет мультидисциплинарный характер, что способствует углублению отношений между научной мыслью, культурой и языком и стало толчком для понимания природы человеческого познания на более высоком, мультидисциплинарном уровне развития науки. 
В последнем меморандуме Римского клуба эта тенденция была обозначена как «идея формирования целостного мировоззрения и нового содержания образования и науки» (Weizsäcker \& Wijkman, 2018).

\section{Методология и методы исследования}

В основу исследования психолингвистического дискурса нейроэкономики положена методология, которая базируется на мультицисциплинарности современных научных исследований.

Растущий интерес к проблемам изучения дискурсивного оформления взаимодействий психолога и адресата, целевых и интенциональных характеристик, среди которых Г. Калмыков (Kalmykov, 2017), выделяет психотерапевтический, психопрофилактический, психокоррекционный, психоконсультативный, психолого-педагогический и др., важно признать одной из приоритетных задач современного дискурсивного подхода в психолингвистике.

Переход науки к мультидисциплинарному дискурсу вызвал необходимость концептуализации, и возможной её операционализации, что влечет необходимость решения таких специфических проблем, которых нет в монодисциплинарных науках.

Применяемый многофакторный анализ мультидисциплинарного характера новых тенденций и закономерностей в развитии экономической теории, роста неопределенности и непредсказуемости в ее институциональной среде создал возможность психолингвистического осмысления значений и структуры новых понятий, терминов и дефиниций. Это стало важным компонентом для установления объективной научной истины, а также коммуникаций в более широком научном диапазоне.

Применение метода сравнительного анализа позволяет строить на фактическом материале научные гипотезы относительно дальнейшего пути развития нейроэкономики, что стимулирует развитие и конкретизацию психолингвистических знаний, способствует их практическому использованию.

В процессе психолингвистического дискурса нейроэкономики использовался, также такой метод научного исследования, как 
экстраполяция. Его результаты являются одной из важных составляющих научного объяснения психолингвистического анализа сложных мультидисциплинарных взаимодействий.

\section{Результаты исследования}

Мультицисциплинарность научных исследований предполагает владение ученными языком однородного речевого сообщества и избегание ошибок в использовании языка. Ни одно из научных исследований не обходится без анализа понятий, дефиниций, терминов. Ученые утверждают, что психолингвистическая сфера человека настолько велика, насколько человеческий мозг может думать. Например, трудно представить, как языковые единицы находятся в узлах мозга человека. В процессе своей мыследеятельности мы являемся свидетелями того, что иногда говорим, не задумываясь, и радуемся тому, что другие люди нас понимают, о чем мы говорим. Такой феномен способствует развитию языковой компетенции. По мнению Н. Хомского,

«языковая компетенция - часть ментальной реальности, а психолингвистическая теория, относящаяся к ней, как своего рода менталистической теорией» (Chomsky, 1965).

В этой теме важным является психолингвистическое содержание языковых процессов в общении и разуме, что позволяет человеческим языкам объяснить, как появляются уникальные и автономные системы в психической сфере человека и изучить их имманентные структуры. Об этом Н. Хомский детально излагает в созданной ним теории иннатизма» (innatismo). Ученый доказывает:

«будучи детьми, мы биологически запрограммированы на язык.

С рождения у человека познавательно заложены врожденные средства, необходимые для изучения языка» (Chomsky, 1965).

Д. Каплан (Caplan, 1987) дополняет это понимание, считая, что некоторые языковые структуры, особенно некоторые синтаксические структуры, и ментальные процессы, которые их реализуют, весьма специфичны и сильно отличаются от любых ранее описанных неязыковых умственных действий людей. По этой причине они должны считаться уникальными и автономными. 
Мультидисииплинарный характер психолингвистического...

Современные практики мультидисциплинарного взаимодействия предполагают самые разные сближения, какими бы странными на первый взгляд они не казались. Одним из таких, является сближение и взаимодействие психолингвистики и нейроэкономики, что в современной экономической теории стало одной из одной из важнейших тем. Психологи признают, что экономика очень точная область науки с гораздо более длинной историей, чем психология. Однако для изучения экономического поведения она нуждается в поддержке со стороны так называемых, социальных, поведенческих наук, стимулируя новые подходы и новые теоретические представления. Вследствие парадигмальных сдвигов в мире современной экономики произошло продуцирование новых сфер экономической теории, таких как нейроэкономика и ее субдисциплины. В процессе их формирования возникла необходимость в соответствующих дефинициях, научных предметах исследования, что требует их оформления и определения, как по форме, так и по содержанию. Создание новых дефиниций, терминов, а также хранения абстрактных лингвистических знаний вызвало необходимость активации соответствующих связей в правильном использовании психолингвистических формул. Многие новые дефиниции изобилуют тонкими различиями. Следует заметить, что само слово «язык» связано не только с различными концепциями или идеями, но также «обременено» различными дополнительными убеждениями, ассоциациями, а иногда и эмоциональными формами. Кроме того, слово «язык» используется как в дискурсах, так и в повседневных, разговорных контекстах, а также в контексте специальной, профессиональной деятельности (Stern, 1983).

Преодоление лексического барьера связано с овладением определенным терминологическим словарем, являющимся существенной опорой в формировании необходимых коммуникативных компетенций. Ученые, которые обладают коммуникативной компетентностью знания, имеют гораздо более широкую компетентность, чем это предусматривает компетенция лингвистическая. В коммуникативной компетенции, считает Р. Хадсон, важно не просто ссылаться только на знание лингвистических форм, а, кроме этого, включать также суть научные знания, и в таком случае, более уместен термин «способность» использования языковых форм (Hymes, 1972). 
Психолингвисты (Pavlova, Zachesova \& Grebenshhikova, 2018) изучают, как значение слова, значение предложения и дискурс-смысл вычисляется и представлен в уме; как сложные слова и предложения составляются в речи и как они разбиваются на составляющие в актах слушания и чтения. Отсюда возникает необходимость в теоретическом и системном поиске функционального значения психолингвистического контекста новых дефиниций. Результатом может стать концептуальная система для дискурсивного общения специалистов в разных областях науки на уровне их профессионального понимания. В условиях дискурса интенциональное состояние собеседников определяет направленность на партнера и текущую коммуникацию. При этом, наряду с интенциям, возникающими по ходу взаимодействия (ответить, уточнить, подтвердить), движение разговора обусловливают и более общие устремления, формирующиеся за рамками диалога в связи с практической деятельностью коммуникантов.

Это предполагает логичный, упорядоченный и целостный анализ материала, содержащегося в новых значениях, терминах и дефинициях, с точки зрения их смысла и структуры.

\section{Концептуальное обобщение мультидисциплинарного психолингвистического дискурса}

Ученые-психолингвисты опираются на мультидисциплинарный характер дискурса смежных областей знания, в том числе и на такие понятия лингвистической типологии, как фонология, синтаксис и семантика (чистая лингвистика). Концептуальная цель психолингвистики состоит в том, чтобы найти лингвистическую и психологически обоснованную теорию языка, конструкцию, способную объяснить язык и процесс его освоения. Таким образом, психолингвисты пытаются объяснить суть языковой структуры и то, как она приобретается и используется в речи, и понимать высказывания. На практике психолингвисты примененяют своеобразный гибрид сугубо лингвистических и психологических знаний в таких вопросах, как общение, человеческий разум, диалекты, фонетизация и творение, а также другие социальнопсихологические проблемы. Психолингвистические исследования показали, что многие концепции, используемые при анализе 
звуковой структуры, структуры слов и структуры предложений также играют важную роль в обработке языка. Тем не менее, для учета языковой обработки также необходимо, чтобы мы понимали, как эти лингвистические концепции взаимодействуют с другими аспектами человеческой деятельности, что позволяет создавать и понимать язык.

Для того, чтобы говорить на каком-то языке необходимо иметь грамматику, которая была усвоена человеком в голове на протяжении его жизни. Лингвисты, которые пишут грамматику, выдвигают гипотезы об усвоенной системе. Термин «грамматика» используется с целью внутреннего представления языка в сознании человека. Ключевым является то, что грамматика - это вопрос не только структуры предложений, но также фонологии, синтаксиса и семантики (Рис. 1).

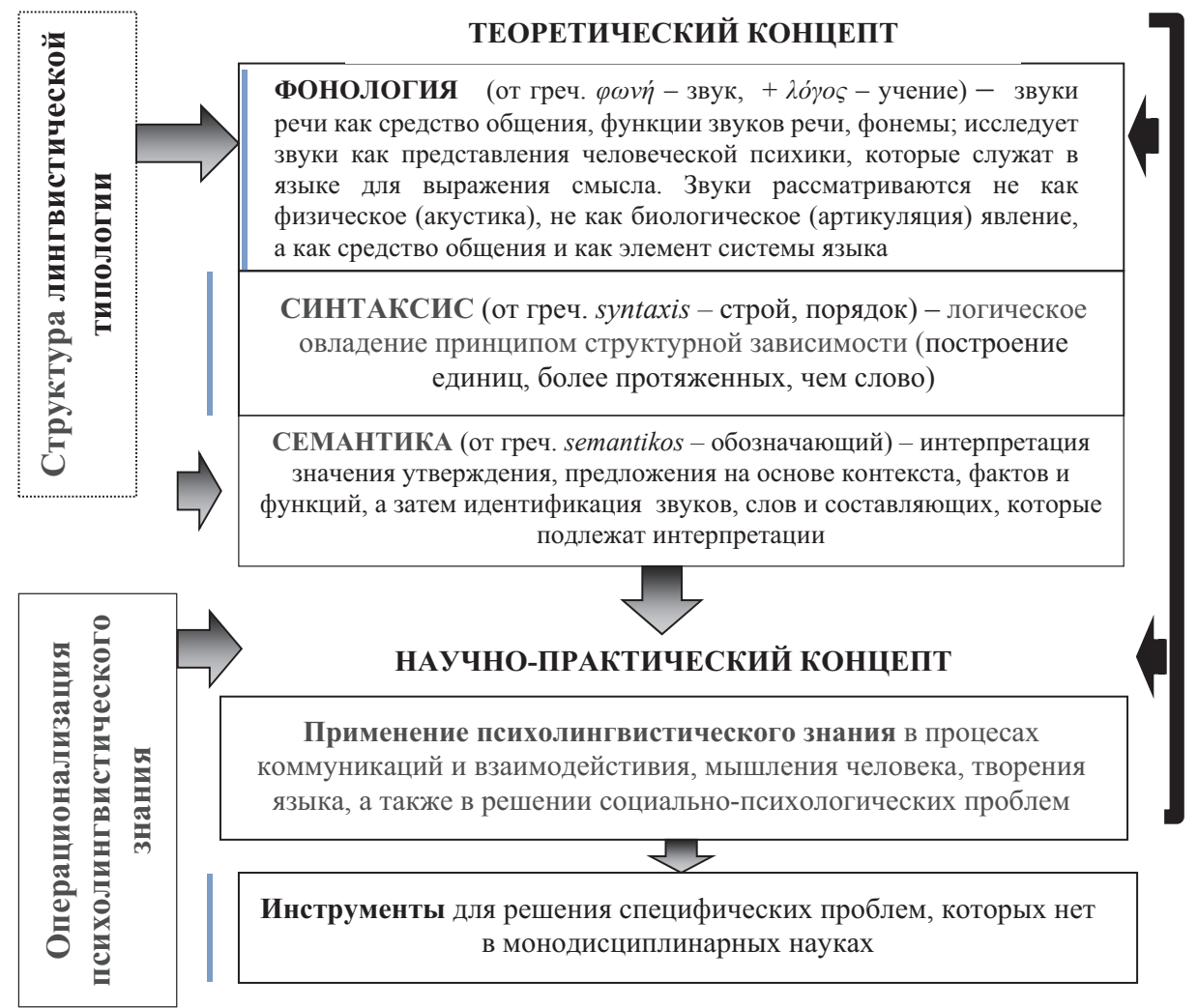

Рис. 1. Мультидисииплинарная модель психолингвистического дискурса 
В большинстве областей изучения языка он - язык рассматривается главным образом в терминах письменного слова, поскольку именно в этой форме мы обычно фиксируем записи важных идей. Относительно мало внимания уделяется чему-то столь же мимолетному и ничем не примечательному, как разговорная речь. В психолингвистике, однако, устная речь, а не письмо, считается более важной частью человеческого языка по нескольким причинам. Bo-nервых, люди использовали разговорные языки в течение 100000 лет, возможно, дольше. Bo-вmopblx, письменность - относительно недавняя разработка, которой всего несколько тысяч лет. Даже сегодня большинство из 7000 языков мира не имеют устоявшейся системы письма. Но нет общества, которое общается просто письменно, без разговорного языка. Так, например, дети учатся говорить задолго до того, как они научатся читать и писать. Изучение разговорного языка у них происходит без формального обучения. Обычно мы воспринимаем процессы производства и распознавания речи как нечто само собой разумеющееся, они включают в себя целый ряд удивительно сложных умственных способностей - часть того, что мы знаем о языке, на котором мы говорим. Слова, которые мы хотим выразить, кажутся необъяснимыми из наших уст, как звуковые волны. Какая психическая система может лежать в основе этой способности производить и распознавать речь? Какие аспекты этой системы кажутся общими для всех людей, и какие аспекты варьируются от языка к языку? Такого рода вопросы относятся к области фонетики и фонологии (оба от греческого корня фон - «звук»), двух подполей лингвистики, связанных со звуками речи.

Понимание, наряду со знанием, достигается, прежде всего, исходя из структуры предложения, т.е. посредством синтаксического подхода. Синтаксис в структуре образования является наиболее важной основой, в силу того, что основное исследование психолингвистики в значительной степени опирается на синтаксические правила. Главная цель психолингвистики - «найти» теорию языка, которая бы подходила и превосходила лингвистику и психологию, и была бы способной объяснить природу языка и его освоение. Другими словами, психолингвистика пытается объяснить природу структуры языка и то, как эта структура получается и используется при порождении и понимании предложений 
(высказываний). В практическом плане психолингвистика пытается применить лингвистические и психологические знания к таким вопросам, как исследование, преподавание и изучение языка.

Синтаксический и семантический подходы являются важными в понимании языка, наряду со знанием. Понимание осуществляется путем распознавания звуков, слов и словосочетаний, содержащихся в предложении, чтобы уловить смысл утверждений, содержащихся в предложении.

Кроме того, понимание происходит также с помощью семантического подхода, что осуществляется путем предоставления интерпретации значения утверждения, предложения, которое он получает, на основе контекста, фактов и функций, а затем идентифицируют звуки, слова и составляющие, которые поддерживают интерпретацию. Оба подхода на практике используются одновременно. Из этих определений становится ясно, что психолингвистика - это междисциплинарная наука, рожденная в результате осознания того, что изучение языка является очень сложным вопросом. Таким образом, одна дисциплина науки не может и не может объяснить язык. Такое междисциплинарное сотрудничество не является чем-то новым в области науки. Другие междисциплинарные науки, такие как нейропсихология, социолингвистика, психофизиология, психобиология, психофармакология и так далее.

\section{Институционализация нейропсихологического знания}

\section{в экономической теории}

С начала 1980-х годов экспликация новых разделов нейроэкономики стала центром внимания не только в экономической науке, но и в нейропсихологии. Это связано с тем, что в течение последних 20-30 лет прошлого столетия в экономических науках все большее значение приобретает важность психологического знания. Этому способствовало, прежде всего, влияние глобализации, развитие современных технологий, а также расширение и смена традиционных научных сфер.

Ф. Культер, В. Клеин и С. Левинсон (Cutler, Klein \& Levinson, 2005) утверждают, что исследователь не должен быть или только психологом, или только лингвистом в равной степени. И далее уточняют: ученый может быть, прежде всего, психологом, но таким, 
который изучает лингвистическое поведение, или лингвистом, но таким, который использует психологические методы, позволяющие исследовать лингвистическое поведение. Чаще всего случается нежелание психолингвистов-психологов углубляться в теоретикоязыковедческие нюансы, а со стороны психолингвистов-языковедов отсутствие веры в точность психологических методов.

Таким образом, основная идея интерпретации научных фактов и их взаимных импликаций, то есть фактически объектом исследований, является стремление найти внутри новой, полной и, в то же время, открытой системы непрерывно возникающих знаний мультидисциплинарную общность, что является логической формой вклада в развитие психолингвистической науки. Следовательно, широкий спектр полученных знаний путем психолингвистических исследований никогда бы не возник только внутри самой лингвистики, будучи только психологическим. Вместе с тем, психолингвистические подходы обогащают знания о языке, но, что не менее важно, расширяются знания и о когнитивных процессах человек. Ведь психолингвистика изучает то, как люди приобретают, интерпретируют и используют язык. Тем самым подобные исследования включают в себя нейробиологические факторы.

В 1990-х годах определилась нейроэкономика (neuroeconomics) как наука, которая занимается исследованием причин и прогнозированием будущего поведения человека в сфере широко понимаемой экономики. Эта наука интегрирует познания в нескольких областях науки: неврологии, психологии, экономики, психолингвистики, когда появились возможности использования существующего опыта экономистов, неврологов и психологов для изучения общих научных целей. Первоначально нейроэкономика возникла в результате изучения биологических основ экономического познания и экономического поведения. Нейрохимические механизмы регуляции функционального состояния мозга (области мозга, нейроны, гены, нейромедиаторы) стали основными биологическими микрофундаментами в изучении экономического поведения человека. Таким образом, общими чертами экономики, психологии и неврологии стали поиск причин явлений, связанных с человеческими решениями, создание поведенческих теорий и прогнозирование будущего поведения на их основе (Walker, 1978). Ученные пришли к признанию того факта, что экономическое 
познание включает в себя память, предпочтения, эмоции, мысленные представления, ожидания, восприятие, обработку информации, умозаключения, интуицию и субъективный опыт (Camerer, Loewenstein \& Prelecl, 2005), что в классической экономике не привлекало особого внимания. И возникла необходимость связать все эти процессы в единую терминологию, дефиницировать их, что и составляет основную задачу психолингвистики - связать слова в процессе взаимодействия людей в любом акте общения, в данном случае, научных, исследовательских коммуникаций.

Динамика таких изменений выходит за рамки формальных институциональных решений. Основными направлениями исследований в области нейроэкономики, где были сосредоточены интересы ученых, стали построение и эмпирическая проверка биологически обоснованных моделей, которые связывают когнитивные структуры мозга с экономическим поведением. Результат поразил научный мир. В 2002 году Нобелевскую премию в области экономики получил психолог Даниэль Канеман (Daniel Kahneman) за попытку объяснить идиосинкразию в способах принятия решений людьми. Это стало началом институционализации психологического знания, которое в экономической теории не вписывалось в ортодоксальные рамки. Сейчас Даниэля Канемана называют «самым влиятельным живым психологом в мире».

В 2017 году признание того, что психология все больше и больше входит в современную экономику, стало, также, награждение экономиста Ричарда Талера (Richard Thaler) Нобелевской премией. Ричард Талер, аналогично Д. Канеману, включил психологические предположения в анализ экономических решений, вследствие чего стал основоположником теории подталкивания (Nudge Theory). Эта теория основана на психологических особенностях индивидуального выбора. Исследуя, как интуитивные инстинкты могут часто отвергать рациональные выборы, Р. Талер (Thaler, 2015) приводит очень убедительный пример по психологии поведения человека. Он предположил, что каждого человека необходимо рассматривать как двух разных людей: один из них планирует, а другой выполняет (или не выполняет) запланированное. Такое психологическое понимание играет главную роль в теории подталкивания. Таким образом, в теории подталкивания детерминируются стимулы влияния на поведение человека. Важно то, что эта теория работает не только 
на индивидуальном, но и на групповом (например, применительно для компаний) уровне.

И в психологических, и в экономических науках (Kaneman \& Tversky, 1979; Thaler, 1991, 2015) на основе поведенческого анализа стали основателями концепций влияния на процесс принятия групповых и индивидуальных решений посредством положительного подкрепления и непрямых указаний.

Анализ новых современных научных теорий сейчас осуществляется в диалектической взаимосвязи психолингвистического, психологического и лингвистического аспектов, их концептов, что способствует выявлению неповторимости, многогранности и глубины этих теорий, а также их механизмов.

Таким образом, нейроэкономика включает в себя как теоретическое моделирование, так и эмпирические исследования. Такой подход способствовал быстрому росту объема эмпирических знаний, что привело к появлению новых научных субдисциплин нейроэкономики. К ним относятся поведенческая экономика, поведенческие финансы, психологическая экономика, экономическая психология, эмоциональная экономика. Эти научные области стали отраслями экономической теории, учитывающей в явном или неявном виде психологические особенности человеческого восприятия. Новые дефиниции катализируют теоретическую интеграцию разных научных сфер, прежде всего, в психолингвистике, как науки, способной к решению проблем, которые не могут быть решены ни в психологии, ни в лингвистике для описания языковой формы речевых высказываний и понятийного аппарата психологии, для описания и объяснения психических процессов производства и восприятия речи, онтогенеза языка и языковой способности как психофизиологической функции человека, формирующейся прижизненно.

\section{Психолингвистический формат поведенческой экономики}

Знакомство с работами (Kahneman \& Tversky, 1974; Thaler, 1991, 2015) по исследованию психологии суждений и принятия решений для многих ученых стали толчком к развитию нового поколения более реалистичных психологических моделей экономического поведения человека. Это послужило основой для 
создания новой сферы нейроэкономики - поведенческой экономики (Behavioral Economics).

В отличие от классической экономики, в которой принятие решений основано на хладнокровной логике, основные положения поведенческой экономики допускают иррациональные действия, а также делают попытку понять, почему это может иметь место. Такая концепция может быть применена к отдельным ситуациям или, в более широком смысле, для охвата более широких действий общества или тенденций на финансовых рынках (Camerer \& Loewenstein, 2004). Таким образом, поведенческая экономика возникла в связи с изучением способности человека прогнозировать экономическое поведение, с разработкой вмешательств, которые изменяют поведение других, управлением индивидуальными интенциями, собственными желаниями, интересами и побуждениями.

В качестве моделей необходимых психолингвистических и коммуникативных навыков ученые-экономисты рассматривают такие, как мотивы людей доверять друг другу, готовность к принятию намеренно нерациональных рисков, относительное оценивание краткосрочных и долгосрочных издержек и выгод, альтруистическое или благотворительное поведение, вредные привычки. Они утверждают, что выбросы дофамина, мозгового гормона удовольствия, могут определять экономическую полезность или ценность (Falk et al., 2013). Таким образом, психолингвистический формат поведенческой экономики интегрирует следующие две составляющие смысла. Наряду с пониманием ценности регулирования иррационального поведения людей, признавая право на эту тенденцию, люди могут составлять лучшие планы на будущее - такие, за которыми «действующие» стороны будут следовать согласовано. Взаимодействие, проникновения и дополнение психодинамики и экономики способствовали созданию поведенческой экономики (Frey \& Stutzer, 2007).

\section{Психолингвистические связи поведенческих финансов}

С помощью законов поведенческой экономики на основе наблюдения в качестве интерпретатора открываются возможности выявления причин аномалии классических моделей поведения, а также объяснения поведения человека. Особенно если поведение 
происходит в условиях неопределенности, изменчивости, причем трудно четко определить детерминанты, существенно влияющие на процесс принятия решений (Wilkinson, 2008). В своих дальнейших исследованиях (Kaneman \& Tversky, 1979; Thaler, 2015), которых сейчас называют одними из основателей новых дисциплин экономической теории, заинтересовались неспособностью традиционной экономической науки объяснить многие эмпирические модели психологии принятия финансовых решений, принятия финансовых рисков, вложения финансов в условиях неопределенности, ведения переговоров. В результате интерпретации психологического содержания финансового поведения сформировалась новая отрасль нейроэкономики поведенческие финансы (Behavioral Finance). Основными компонентами концепции поведенческих финансов, прежде всего, стали когнитивная психология, как наука объясняющая, каким образом мыслят люди, и, непосредственно, теория финансов, изучающая условия эффективности финансовых рынков. Психолингвистические связи поведенческих финансов - это область финансовой науки, а также сфера психологических, социальных и антропологических вопросов, используемых для рассмотрения экономического поведения финансовых рынков и их участников. В этом контексте психолингвистика охватывает когнитивные процессы, которые позволяют генерировать грамматические структуры поведенческих финансов, позволяют понять высказывания, слова, текст в этой сфере.

В настоящее время поведенческие финансы это быстро развивающаяся дисциплина, которая имеет серьезные перспективы в поиске и регулировании определенной инвестиционной среды. Исследования психологов доказывают, что люди делают систематические ошибки в экономическом мышлении. Часто бывает, что люди или чрезмерно уверены в своих финансовых решениях, или пренебрегают своим опытом, или слишком доверяют своим предпочтениям, что часто вводит их в заблуждения и приводит к принятию ошибочных решений.

Тем не менее, попытки интерпретировать основательно различное экономическое поведение часто терпит неудачу, даже когда экономические теории дополняются психологическими знаниями. Ситуации такого рода возникают в случае, когда при 
принятии финансовых решений люди слишком эмоциональны, или, наоборот, апатичны (Ekman, 2016).

Именно поэтому, суть поведенческого подхода к теории финансов представляет собой разнообразные психологические механизмы поведения участников финансового рынка. Поведенческие финансы представляют собой тесную комбинацию индивидуального поведения и рыночных явлений, т.е. используют знания, заимствованные из психологии и теории финансов.

В научных публикациях последних лет по поведенческой экономике ученые эмпирически доказали, что эмоции часто стоят за человеческими решениями, иногда чаще, чем так называемые здравый смысл и рациональность.

Все большее число ученых сходятся во мнении о значимости и влиянии эмоций, чувств и поведения на потенциальные результаты их экономической жизнедеятельности. Целью научного познания, считает Ф. Брентано (Brentano, 1999), является социальная деятельность, которую нужно изучать как интенциональное поведение. Поэтому человеческую деятельность можно попытаться объяснять в ответ на поведение других людей, ища смысл и мотивы человеческой деятельности.

Компании-производители отслеживают, насколько сильные эмоции могут возникнуть, когда дело доходит до укрепления лояльности к определенным производителям. Создание реальных эмоциональных связей побуждает клиентов отдавать значительное конкурентное преимущество этим компаниям.

В исследовании экономического поведения, ученые все больше сходятся во мнении, что мысли, чувства, намерения, коммуникации - все причинно порождаются мозговыми процессами, и именно это является основой для принятия экономических решений. Антонио Дамасио в своих исследованиях нейронных систем, которые лежат в основе памяти, сознания и языка, доказывает, что эмоции играют центральную роль в социальном познании и принятии решений (Damasio, 1994). Известно, что экономические модели принятия решений в классической экономической теории имеют последовательный характер. Они предполагают, что лица, принимающие решения, выбирают между двумя альтернативами: между действиями по оценке целесообразности и вероятности их последствиями, и 
интеграции этой информации на строгой основе математического ожидания. При этом, экономисты ссылаются на целесообразность желаемых результатов как их «полезности», а принятия решений представляется как вопрос максимизация полезности. Однако, как показывает практика, это, не всегда означает, что те, кто принимает решения, не имеют эмоций или иммунитета к их влиянию. Поэтому возникла необходимость изучения значения эмоций в процессе принятия экономических решений, и соответствующая сфера экономической теории получила название эмочиональная экономика (Emotional Economy). Методология эмоциональной экономики основана на результатах исследований различий в некоторых видах эмоциях, которые присутствуют в экономическом поведении людей. Так, например, ожидаемые эмоции (Expected Emotions) - это те, которые ожидаются, как результаты, связанных с различными возможными направлениями действий. Ключевой особенностью ожидаемых эмоций является то, что они испытываются, когда результаты принятия решений материализуются, но не в момент выбора, на момент выбора происходит только предположение о будущих эмоциях. Непосредственные эмоции (Immediate Emotions), напротив, испытываются в момент выбора одного их возможных вариантов решений и попадают в одну из категорий. Первая, - это интегральные эмоции, как и ожидаемые эмоции, которые возникают в результате размышлений о последствиях своего решения, но неотъемлемые эмоции, в отличие от ожидаемых, испытываются в момент выбора. Или вторая категория (Loewenstein, Weber, Hsee, \& Welch, 2001) - под непосредственными эмоциями следует понимать «горячие» интуитивные эмоции, которые испытывают люди, когда они рассматривают конкретный вариант решения на пороге принятия решения. Их называют еще «случайными» эмоциями (Incidental Emotions), которые возникают в момент выбора под влиянием объективных или ситуативных факторов, которые объективно не связанные с поставленной задачей. Для экономистов влияние на принятие решений случайных, сиюминутных эмоций представляет значительно более фундаментальный вызов, потому что такие эмоции, по определению, не имеют отношения к адекватному принятию решений.

Безусловно, что в некоторых случаях, эмоции играют позитивную роль в принятии решений. Но в других случаях, такие 
как страх, неуверенность, эмоции могут провоцировать у людей действовать вопреки своим экономическим интересам. В результате возникает насущная необходимость для исследований причин и последствий влияния эмоций на экономическое поведение человека.

\section{Психологическая экономика как наука о психологических} механизмах, лежащих в основе экономического поведения

На протяжении многих лет экономисты в разной степени осознавали влияние психологии на то, что происходит в сфере экономики. К.-Е. Варнерид (Warneryd, 1999) подчеркивал, что в прошлом столетии расстояние между экономикой и психологией увеличивалось. По его словам, это связано не только с разным характером проблем, рассматриваемых в обеих этих областях, но также с различиями в методологических подходах. В то же время он указывал, что эта ситуация в настоящее время меняется, а именно: можно заметить симптомы взаимного удобства использования и сотрудничества.

В современной науке пути развития психологии и экономик пути все чаще и чаще сходятся, однако экономисты должны больше учиться в области психологических знаний, чем наоборот. Понимание этого стало причиной появление следующей относительно молодой субдисциплины, какой стала экономическая nсихология (Psychological Economics). Психологическая экономика является областью, занимающейся изучением взаимодействия человека с экономическими системами, в результате чего формируются знания об организации экономической реальности, которые хорошо вписываются в психологические теории. Эта научная сфера интегрирует теоретические модели и эмпирические исследования, описывающие предпочтения, суждения, модели выбора экономического взаимодействия и факторов, влияющих на них, а также последствий суждений и решений в таких взаимодействиях.

Это сфера и психологического, и экономического знания, которая изучает поведение людей, связанных с производством, распределением и потреблением товаров, включая мотивацию покупки, использует опросы общественного мнения в качестве метода оценки ожиданий потребителей. Современные исследователи, имеющие дело с обеими сферами знаний 
(экономической и психологической), осознали тот факт, что они могут научиться чему-то полезному друг у друга. Что касается психологов, они внесли свой вклад в изучение экономического поведения, в частности, в процессы принятия решений. В свою очередь, экономисты согласились с методологией исследования, специфичной для психологии. Они начали использовать методы исследования, такие как лабораторный эксперимент, а также представили концепцию и гипотезы в области как социальной, так и когнитивной психологии.

Экономисты согласились с тем, что применение психологии способствует более реальному пониманию экономического поведения человека. Психологи, в свою очередь, демонстрируя сложность человеческой мотивации и восприятия реального мира, помогают установить истинность экономических законов и выборов (Maital, S. \& Maital, S.L., 1993). Таким образом, психология оказала революционное влияние на развитие современной экономической теории.

\section{Выводы}

Обращение к интегральному понятию психолингвистического дискурса позволяет целостно охватить основные аспекты проблемы мультидисциплинарного взаимодействия в развитии современных научных теориях. Долгое время традиционное экономическое мышление считалось адекватным тому, что происходит в окружающем мире. Как казалось, оно представляло собой наилучшие возможные модели мира и поведения людей. Но, с течением времени, стало ясно, что эта теория несовершенна и, по меньшей мере, частична. Происходящие аномалии в действии законов экономики были необъяснимы с помощью традиционных парадигм, и подлежали пересмотру.

Современная психолингвистическая наука активно исследует психологические процессы, происходящие в ходе создания и понимания человеком лингвистических форм. Поэтому для эмпирического анализа выбирается логическая, лингвистическая модель языка, которая учитывает психологические процессы восприятия, мыслительного преобразования и создания языковой 
информации. С этой целью главная цель возникновения современных научных дисциплин, а в данном случае нейроэкономики и еe субдисциплин, состоит не в том, чтобы полностью изменить каким образом следует понимать современную экономическую теорию, или разрушить традиционный экономический образ мышления. Более важным является сближение экономической теории с реальным миром, равно как и с «человеком психологическим» с его эмоциями, характером, интенциями.

Уникальность психолингвистического дискурса нейроэкономики состоит в том, что теории и модели, которые развивались на основе одного учения, систематически проверяются с использованием методов, разработанных другой наукой. Это динамичная и открытая система нового постоянно формирующегося знания.

Революционное влияние на развитие мультидисциплинарных научных исследований, с использованием экономического и психолингвистического знания, оказали прогрессивные достижения в мультидисциплинарных научных исследованиях, которые объединены единым исследовательским интересом.

Дискурсивный анализ мультидисциплинарных исследований предусматривает общение между учеными различных научных направлений, и, следовательно, использование различных научных языков. Отсюда возникает необходимость создания и внедрения унифицированного единого пространства новых знаний, основными характеристиками которых является довольно динамичное развития, в том числе благодаря уровню абстракции (моно, меж- и мультидисциплинарной), что гарантирует успешную методологическую рефлексию.

Психолингвисты, исследуя отношения между языком и мышлением, продолжают предметный спор о том, является ли язык функцией мышления или мышлением как функцией использования языка. Еще недостаточно изучено, каким образом слова оказывают влияние на людей. Психолингвистика является той наукой, которая стремительно развивается и имеет все возможности глубоко исследовать эту научную проблему. Её научно моральный деонтологический долг состоит в том, чтобы делать новые открытия в этой области. Поэтому психолингвистика продолжает развиваться как сложная, междисциплинарная 
Multidisciplinary Nature of the Psycholinguistic Discourse...

область исследования. Большинство проблем в психолингвистике со временем формируются более конкретными, включая изучение лингвистической деятельности и овладение языком. В методологическом смысле, с этой точки зрения, современная психолингвистика является мультициплинарной наукой и возглавляет пирамиду наук мультидисциплинарного характера.

\section{Литература}

Brentano, F. (1999). Psychologia z empirycznego punktu widzenia, przet. Włodzimierz Galewicz, PIW, Warszawa.

Camerer, C., \& Loewenstein, G. (2004). Behavioral Economics: Past, Present, Future. In C. Camerer, G. Loewenstein \& M. Rabin (Eds.), Advances in Behavioral Economics (pp. 3-51). Princeton, NJ: Princeton University Press. https://doi. org/10.1515/9781400829118

Camerer, C., Loewenstein, G., \& Prelec, D. (2005). Neuroeconomics: How Neuroscience Can Inform Economics. Journal of Economic Literature, 43, 9-64. https://doi.org/10.1257/0022051053737843

Caplan, D. (1987). Neurolinguistics and Linguistic Aphasiology. An introduction. Cambridge: Cambridge University Press. https://doi.org/10.1017/CBO9780511620676

Chomsky, N. (1965). Aspects of the Theory of Syntax. Cambridge, Massachusetts: MIT Press. https://doi.org/10.21236/AD0616323

Cutler, A., Klein, W., \& Levinson, S.C. (2005). The Cornerstones of TwentyFirst Century Psycholinguistics. In A. Cutler (Ed.), Twenty-First Century Psycholinguistics. Four Cornerstones (pp. 1-20). Mahwah, NJ: Erlbaum.

Damasio, A. (1994). Descartes' Error: Emotion, Reason, and the Human Brain. New York, NY: G. P. Putnams Sons.

Ekman, P. (2016). What scientists who study emotion agree about. Perspectives on Psychological Science, 11 (1), 31-34. https://doi.org/10.1177/1745691615596992

Falk, E.B., Morelli, S.A., Welborn, B.L., Dambacher, K., \& Lieberman, M.D. (2013). Creating Buzz: The Neural Correlates of Effective Message Propagation. Psychological Science, 24 (7), 1234-1242. https://doi. org/10.1177/0956797612474670

Frey, B.S., \& Stutzer, A. (2007). Economics and Psychology. A Promising New Cross-Disciplinary Field, MIT Press, Cambridge, MA. https://doi.org/10.7551/ mitpress/2604.003.0004

Hymes, D.H. (1972). On Communicative Competence. In J.B. Pride \& J. Holmes (Eds.), Sociolinguistics: Selected Readings (pp. 269-293). Harmondsworth: Penguin.

Kahneman, D., \& Tversky, A. (1974). Judgment Under Uncertainty: Heuristics and Biases. Science, 185 (4157), 1124-1132. Reprinted in Kahneman, D. (2011). Thinking Fast and Slow. London: Penguin, 419-432.

Kalmykov, H. (2017). Profesijno-psihologichnij diskurs yak instrument vplivu na adresata [Professional and Psychological Discourse as an Instrument of Influence on the Addressee]. Psiholingvistika - Psycholinguistics, 22 (1), 104-123. https:// doi.org/10.5281/zenodo.1087770 [in Ukrainian]. 
Kaneman, D., \& Tversky, A. (1979). Prospect Theory: An Anylysis of Decision under Risk. Econometrica, 47 (2), 26-291. https://doi.org/10.2307/1914185

Loewenstein, G., Weber, E.U., Hsee, C.K., \& Welch, N. (2001). Risk as feelings. Psychological Bulletin, 127 (2), 267-286. https://doi.org/10.1037/00332909.127.2.267

Maital, S., \& Maital, S.L. (1993). Psychology and Eco-nomics. In W.S. Maital \& S.L. Maital (Eds.), Economics and Psychology (pp. 3-35). Brookfield: Edward Elgar Company Press.

Pavlova, N., Zachesova, I., \& Grebenshhikova, T. (2018). Vzaimoponimanie partnerov $\mathrm{V}$ diskurse [Mutual Understanding Between Partners in Discourse.]. Psiholingvistika - Psycholinguistics, 24 (1), 269-288. https://doi. org/10.31470/2309-1797-2018-24-1-269-288 [in Russian].

Stern, H.H. (1983). Fundamental Concepts of Language Teaching. Oxford, England: Oxford University Press.

Thaler, R.H. (1991). Quasi-Rational Economics. New York: Russell Sage Foundation.

Thaler, R.H. (2015). Misbehaving: The Making of Behavioral Economics. W.W. Norton \& Company, Inc., New York.

Walker, E. (Ed.). (1978). Explorations in the Biology of Language. Montgomery, Vermont: Bradford Books, and Hassocks, Sussex: Harvester Press. https://doi. org/10.1017/S0022226700006848

Warneryd, K.-E. (1999). The Psychology of Saving: A Study on Economic Psychology. Cheltenham, UK, Northampton, MA: Elgar.

Weizsäcker, E., \& Wijkman, A. (2018). Come on!: Capitalism, Short-termism, Population and the Destruction of the Planet - a Report to the Club of Rome. New York, NY: Springer Science + Business Media LLC. https://doi. org/10.1007/978-1-4939-7419-1

Wilkinson, N. (2008). An Introduction to Behavioral Economics. New York: Palgrave Macmillan.

\begin{abstract}
АННОТАЦИЯ
Вступление. Статья посвящена вопросам мультидисциплинарного взаимодействия новых научных направлений, которые предполагают самые разнообразные сближения, какими бы странными на первый взгляд они не казались. Одним из таких феноменов является взаимодействие психолингвистики и нейроэкономики.

Цель исследования. В статье исследуется переход современной науки к мультидисциплинарному дискурсу, что вызывает необходимость концептуализации и возможной операционализации методами психолингвистики. Концептуализация новых направлений нейроэкономики, в психолингвистическом контексте, предполагает некий ментальный опыт, включающий кроме процессов создания новых концепций и контекстуального экономического знания, также определение роли интересов, интенций, эмоций в экономической деятельности человека.
\end{abstract}

Методы исследования. Многофакторный анализ, сравнительный анализ, экстраполяция. 
Результаты. В последние десятилетия формирование новых областей экономической науки, а именно тех, которые связаны с развитием нейроэкономики, значительно расширили поле психолингвистики. Продуцирование новых парадигм экономической теории, формирование соответствующих дериниций, научных предметов требуют орормления и их определения как по форме, так и по содержанию. Рассматривается необходимость теоретического и упорядоченного определения функционального значения психолингвистического контекста новых дефиниций, результатом которого может стать концептуальная система для общения специалистов в разных областях науки на уровне их профессионального понимания. Представляется, что чентральными вопросами в психолингвистическом дискурсе нейроэкономики стала взаимосвязь между экономикой, психологией, лингвистикой и психолингвистикой. Такая связь, несомненно, имеет мультидисциплинарный характер, что способствует углублению отношений между научной мыслью, культурой и языком и стало толчком для понимания природы человеческого познания на более высоком, мультидисциплинарном уровне развития науки. Это является необходимым компонентом для осмысления значений и структуры понятий, терминов и дефиниций, а также коммуникаций на более высоком научном уровне.

Выводы. Новые сферы нейроэкономики такие как поведенческая экономика, поведенческие финансы, эмоциональная экономика, психологическая экономика, стали самостоятельными разделами экономической теории, которые, в явном или неявном виде, учитывают психологические особенности человеческого восприятия и поведения в процессе хозяйственной деятельности. Эти дефиниции катализируют теоретическую интеграцию разных научных сфер, и, прежде всего, психолингвистическую науку.

Ключевые слова: мультидисциплинарный характер исследований, психолингвистический дискурс, нейроэкономика, поведенческая экономика, поведенческие финансы, психологическая экономика, эмочиональная экономика.

\section{Ткач Тамара, Ткач Анатолій \& Рекун Іван. Мультидисциплінарний характер психолінгвістичного дискурса нейроекономіки}

\section{АНОТАЦІЯ}

Вступ. Статтю присвячено питанням мультидисциплінарної взаємодії нових наукових напрямків, які передбачають найрізноманітніші зближення, якими б дивними, на перший погляд, вони не видавалися. Одним з таких феноменів $\epsilon$ взаємодія психолінгвістики і нейроекономіки.

Мета дослідження. у статті досліджуться перехід сучасної науки до мультидисциплінарного дискурсу, що викликає необхідність концептуалізації та можливої операціоналізації методами психолінгвістики. Концептуалізація нових напрямків нейроекономіки в психолінгвістичному контексті передбачає певний ментальний досвід не тільки у процесах формування нових концепцій 
Мультидисииплинарныц̆ характер психолингвистического...

і контекстуального економічного знання, а також визначення ролі інтересів, інтенцій, емоцій в економічній діяльності людей.

Методи дослідження. Багатофракторний аналіз, порівняльний аналіз, екстраполяція.

Результати. Останніми десятиліттями розвиток нових галузей економічної науки, а саме тих, які пов'язані з розвитком нейроекономіки, значно розширили поле психолінгвістики. Продукування нових парадигм економічної теорії, формування відповідних дефрініцій, наукових предметів вимагають оформлення та їх визначення як за формою, так і за змістом. Розглядається необхідність теоретичного $i$ впорядкованого визначення функціонального значення психолінгвістичного контексту нових дефрініцій, результат якого може стати концептуальною системою для спілкування фахівців різних галузей науки на рівні їх професійне розуміння. Визначено, що центральні питання нейроекономіки в психолінгвістичному дискурсі стали взаємозв'язком між економікою, психологією, лінгвістикою і психолінгвістикою. Такий зв'язок, безсумнівно, має мультидисциплінарний характер, що сприяє поглибленню відносин між науковою думкою, культурою $і$ мовою $i$ стало поштовхом для розуміння природи людського пізнання на більш високому, мультидисциплінарному рівні розвитку науки. Це є необхідним компонентом для осмислення значень і структури понять, термінів і дефініцій, а також комунікацій на більш високому науковому рівні.

Висновки. Нові сфери нейроекономіки такі як поведінкова економіка, поведінкові фінанси, емоційна економіка, психологічна економіка, стали самостійними розділами економічної теорії, які, в явному чи в неявному вигляді, враховують психологічні особливості людського сприйняття $i$ поведінку в прочесі господарської діяльності. Ці дефініції каталізують теоретичну інтеграцію різних наукових сфрер, i, перш за все, психолінгвістичну науку.

Ключові слова: мультидисциплінарний характер дослідження, психолінгвістичний дискурс, нейроекономіка, поведінкова економіка, поведінкові фінанси, емоційна економіка, психологічна економіка. 